\title{
PERBEDAAN HASIL BELAJAR SISWA DENGAN MENGGUNAKAN MODEL PELATIHAN BERBASIS METODE PRAKTIKUM
}

\author{
Siska Mauritha \\ Fakultas Pertanian, Universitas Teuku Umar \\ e-mail: msieskha@gmail.com
}

\begin{abstract}
Abstrak: Penelitian ini bertujuan untuk mengetahui hasil belajar siswa yang diajar dengan menggunakan model pelatihan berbasis metode praktikum di SMAN 1 Meulaboh T. P 2016/ 2017. Metode penelitian yang digunakan adalah Eksperimen, dan desain penelitian adalah Pretest-Posttest Control Group Design. Populasi penelitian adalah siswa kelas X SMAN 1 Meulaboh yang terdiri dari enam kelas setiap kelas berjumlah 40 siswa, dan kelompok sampel ditentukan dengan teknik random sampling sehingga diperoleh dua kelas yang menjadi sampel penelitian. Instrumen yang digunakan adalah tes bentuk pilihan berganda yang telah ditentukan validitas dan reliabilitasnya sebanyak 20 soal.Kemudian pada sampel diberikan perlakuan yang berbeda, kelas eksperimen menggunakan model pelatihan berbasis metode praktikum dan kelas kontrol menggunakan pembelajaran konvensional. Pada awal pembelajaran siswa diberikan pretes dengan hasil rata - rata kelas eksperimen 28,4 dan kelas kontrol 27,8. Setelah pembelajaran selesai diperoleh postes dengan hasil rata - rata kelas eksperimen 81,5 dan kelas kontrol 69,1. Hasil uji $\mathrm{t}$ diperoleh $t_{\text {hitung }}=5,08$ dan $t_{\text {tabel }}=1,9$, sehingga $t_{\text {hitung }}>t_{\text {tabel }}$ maka $\mathrm{H}_{\mathrm{o}}$ ditolak, dengan demikian diperoleh kesimpulan bahwa ada perbedaan hasil belajar antara kelas eksperimen yang menggunakan model pelatihan berbasis metode praktikum dan kelas kontrol yang menggunakan pembelajaran konvensional selama kegiatan belajar mengajar di SMAN 1 Meulaboh T.P 2016 / 2017.
\end{abstract}

\section{Kata Kunci: model pelatihan, metode praktikum.}

\section{DIFFERENCE LEARNING RESULTS STUDENT USING TRAINING MODEL BASED ON PRACTICUM METHOD}

\begin{abstract}
This study aims to find out the learning outcomes of students taught by using practice-based training methods at SMAN 1 Meulaboh T. P 2016 / 2017. The research method used is Experiments, and research design is Pretest-Posttest Control Group Design. The population of the study were the students of grade X SMAN 1 Meulaboh consisting of six classes of each class of 40 students, and the sample group was determined by random sampling technique to obtain two classes that became the research sample. The instrument used is multiple choice form test that has been determined the validity and reliability of 20 questions. Then in the sample given different treatment, the experimental class using the training model based on practicum method and control class using conventional learning. At the beginning of the learning the students were given pretest with the average results of the experimental class 28.4 and the control class 27.8. After the learning was completed the postes were obtained with the average result of the experimental class 81,5 and the control class 69.1. The result of $t$ test is $t_{\text {count }}=5.08$ and $t_{\text {table }}=1.9$, so $t_{\text {count }}>t_{\text {table }}$ then $H_{o}$ is rejected, thus obtained the conclusion that there is difference of learning result between experimental class using training model based on practicum method and control class using conventional learning during teaching and learning activities at SMAN 1 Meulaboh TP 2016/2017.
\end{abstract}

Keywords: training model, practicum method. 


\section{PENDAHULUAN}

Pada umumnya guru dalam mengajarkan materi fisika cenderung menggunakan pembelajaran konvensional yaitu penyampaian materi pembelajaran dengan metode ceramah. Hal ini juga terjadi pada sekolah yang akan diteliti sebagaimana diperoleh hasil observasi peneliti disekolah tersebut bahwa dalam mengajari materi - materi fisika guru bidang studi menggunakan metode ceramah, diskusi dan demonstrasi sehingga berdampak pada hasil belajar siswa yang rendah dan hanya menguasai teori saja daripada praktek. Metode praktikum jarang digunakan karena keterbatasan alat - alat yang disediakan dilaboratorium sekolah tersebut. Menurut Halimah (2012), “ Metode Praktikum diartikan sebagai suatu kegiatan belajar mengajar dengan cara melibatkan peserta didik mengalami dan membuktikan sendiri proses dan hasil suatu percobaan". Oleh sebab itu, peneliti mengajukan penggunaan metode praktikum dalam proses belajar mengajar materi fisika dalam upaya peningkatan hasil belajar siswa. Menurut Sumintono (2010), “Kegiatan praktikum laboratorium dapat meningkatkan sikap kritis, keterampilan proses sains, ataupun sikap ilmiah siswa".

Adapun kendala yang dihadapi peneliti sebelumnya pada saat menggunakan metode praktikum adalah sebagaimana diungkapkan oleh Kurnianto (2010), " Siswa masih salah dalam membuat laporan awal dan kurang berhati - hati dalam merangkai alat". Untuk mengatasi permasalahan tersebut, peneliti akan memberikan contoh format laporan awal kepada siswa dan meminta siswa mengisi bon pinjam alat setiap kali melakukan percobaan. Dalam penelitian ini, peneliti menggunakan Model Pelatihan disebabkan model ini dirancang berdasarkan asumsi bahwa orang dapat belajar melalui observasi dan praktek. Keberhasilannya ditunjukkan melalui perilaku yang dapat diamati, seperti kemampuan memecahkan permasalahan matematis. Kesimpulan dari penelitian Wibowo (2009), " Pada pembelajaran dengan menggunakan Model Pelatihan berbasis praktikum siswa lebih aktif dalam melakukan pembelajaran, hal ini karena siswa diberi kesempatan untuk membuktikan suatu teori fisika".

Berdasarkan uraian diatas, permasalahan yang terdapat di SMAN 1 Meulaboh adalah (1) Rendahnya hasil belajar siswa pada materi besaran dan satuan di kelas X ; (2) Siswa lebih banyak belajar teori tanpa disertai praktikum; (3) Laboratorium kurang dimanfaatkan karena keterbatasan alat ; (4) pemahaman konsep - konsep dasar fisika masih kurang. Oleh karena itu, yang menjadi rumusan masalah dalam penelitian ini adalah Apakah ada perbedaan hasil belajar siswa dengan menggunakan Model Pelatihan berbasis metode praktikum dan Pembelajaran konvensional pada materi besaran dan satuan di kelas X semester 1 di SMAN 1 Meulaboh T.P. $2016 / 2017$.

\section{METODE}

\section{Populasi dan Sampel Penelitian}

Penelitian ini dilaksanakan di kelas X SMAN 1 Meulaboh pada semester I bulan Juli 2017. Populasi dalam penelitian ini adalah seluruh siswa kelas X SMAN 1 Meulaboh yang berjumlah 240 orang dan terdiri dari enam kelas. Sampel dalam penelitian terdiri dari dua kelas yaitu kelas eksperimen dan kelas kontrol masing - masing terdiri dari 40 orang yang ditentukan dengan teknik cluster random sampling.

\section{Metode Penelitian}

Penelitian ini menggunakan metode Eksperimen dengan desain penelitian yaitu: PretestPosttest Control Group Design.

\section{Instrumen Penelitian}

Instrumen yang digunakan adalah tes bentuk pilihan berganda yang telah ditentukan validitas dan reliabilitasnya sebanyak 20 soal. 


\section{Teknik Analisis Data}

Peningkatan pembelajaran ditentukan dengan uji statistik terhadap peningkatan rata - rata hasil belajar siswa sebelum dan setelah pelaksanaan praktikum. Uji statistik yang digunakan ditentukan setelah dilakukan uji normalitas (uji Lillifors) dan homogenitas (uji Varians) terhadap data hasil belajar siswa. Besar peningkatannya dengan indeks gain $<\mathrm{g}>$ dan kemudian dihitung nilai $\mathrm{N}$-gain dari kedua kelas. Pengujian hipotesis menggunakan uji $\mathrm{t}$ dua pihak. Seluruh data kuantitatif yang diperoleh dari penelitian ini diolah dengan bantuan program Microsoft Excel 2007.

\section{HASIL}

Berdasarkan hasil tes yang telah dilakukan di SMAN 1 Meulaboh, maka diperoleh data mengenai pembelajaran menggunakan model pelatihan berbasis metode praktikum dan pembelajaran konvensional pada materi pokok besaran dan satuan. Hasil belajar ranah kognitif kelas eksperimen dan kelas kontrol pada SMAN 1 Meulaboh sebelum diberi perlakuan diberikan pretest terlebih dahulu untuk mengetahui kemampuan awal siswa dengan hasil pretest berada pada kategori tidak tuntas dengan rata - rata 28,4 untuk kelas eksperimen dan 27,8 untuk kelas kontrol seperti pada tabel berikut:

Tabel 1. Data Hasil Pretest Siswa SMAN 1 Meulaboh
\begin{tabular}{|l|l|l|l|l|l|l|l|}
\hline \multicolumn{7}{|c|}{ Data pretest siswa } \\
\hline \multicolumn{7}{|c|}{ Kelas Eksperimen } & \multicolumn{7}{c|}{ Kelas Kontrol } \\
\hline Nilai & Kategori & $\mathrm{f}_{\mathrm{i}}$ & $\mathrm{f}_{\mathrm{k}}$ & Nilai & Kategori & $\mathrm{f}_{\mathrm{i}}$ & $\mathrm{f}_{\mathrm{k}}$ \\
\hline 10 & TT & 3 & 3 & 15 & TT & 4 & 4 \\
\hline 15 & TT & 5 & 8 & 20 & TT & 10 & 14 \\
\hline 20 & TT & 6 & 14 & 25 & TT & 7 & 21 \\
\hline 25 & TT & 5 & 19 & 30 & TT & 6 & 27 \\
\hline 30 & TT & 4 & 23 & 35 & TT & 6 & 33 \\
\hline 40 & TT & 7 & 30 & 35 & TT & 4 & 37 \\
\hline 45 & TT & 6 & 36 & 40 & TT & 2 & 39 \\
\hline 50 & TT & 4 & 40 & 45 & TT & 1 & 40 \\
\hline Jumlah $=1135$ & 40 & Jumlah $=1110$ & & 40 \\
\hline Rata - rata $=28,4$ & Rata - rata $=27,8$ \\
Ket: ${ }^{*}$ TT $=$ Tidak Tuntas
\end{tabular}

Setelah diperoleh hasil data pretest siswa, kemudian dilakukan pengujian data melalui pengujian normalitas dan homogenitas data sebagai syarat kelayakan penelitian disekolah tersebut. Dari hasil pengujian normalitas dengan uji lilliefors diperoleh kesimpulan bahwa data pretest siswa untuk kedua kelompok sampel memiliki data yang normal sedangkan pengujian homogenitas data pretest siswa dengan menggunakan uji $\mathrm{F}$ diperoleh kesimpulan bahwa data pretest siswa antara kelompok sampel tersebut dinyatakan dapat mewakili seluruh populasi yang ada.

Kemudian pada kedua kelompok sampel diberikan perlakuan yaitu model pelatihan berbasis metode praktikum di kelas eksperimen dan pembelajaran konvensional di kelas kontrol. Pada akhir pembelajaran, dilakukan posttest untuk mengetahui hasil belajar kedua kelompok sampel setelah diberikan perlakuan. Dari hasil penelitian ini diperoleh pada kelas eksperimen mendapatkan nilai rata - rata 81,5 termasuk ke dalam kategori tuntas baik dan kelas kontrol mendapatkan nilai rata - rata 69,1 yang termasuk dalam kategori cukup tuntas dengan 6 siswa yang mendapat kategori kurang tuntas untuk kelas eksperimen dan 18 siswa termasuk kategori cukup tuntas untuk kelas kontrol seperti terlihat pada tabel 2 berikut: 


\section{PEMBAHASAN}

\begin{tabular}{|c|c|c|c|c|c|c|c|}
\hline \multicolumn{8}{|c|}{ Data posttest siswa } \\
\hline \multicolumn{4}{|c|}{ Kelas Eksperimen } & \multicolumn{4}{|c|}{ Kelas Kontrol } \\
\hline Nilai & Kategori & $\mathrm{f}_{\mathrm{i}}$ & $f_{k}$ & Nilai & Kategori & $\mathrm{f}_{\mathrm{i}}$ & $f_{k}$ \\
\hline 60 & KT & 3 & 3 & 50 & CT & 6 & 6 \\
\hline 70 & KT & 3 & 6 & 60 & $\mathrm{CT}$ & 6 & 12 \\
\hline 75 & $\mathrm{CT}$ & 8 & 14 & 65 & $\mathrm{CT}$ & 6 & 18 \\
\hline 80 & TB & 8 & 22 & 70 & TB & 5 & 23 \\
\hline 85 & TB & 8 & 30 & 75 & TB & 6 & 29 \\
\hline 90 & ST & 4 & 34 & 80 & ST & 6 & 35 \\
\hline 95 & ST & 2 & 36 & 85 & ST & 3 & 38 \\
\hline 100 & ST & 4 & 40 & 90 & ST & 2 & 40 \\
\hline \multicolumn{2}{|c|}{ Jumlah $=3260$} & \multicolumn{2}{|c|}{40} & \multicolumn{2}{|c|}{ Jumlah $=2765$} & \multirow{2}{*}{\multicolumn{2}{|c|}{40}} \\
\hline \multicolumn{4}{|c|}{ Rata - rata $=81,5$} & \multicolumn{3}{|c|}{ Rata - rata $=69,1$} & \\
\hline $\begin{array}{r}{ }^{*} \text { KT } \\
\text { CT } \\
\text { TB } \\
\text { ST }\end{array}$ & $\begin{array}{l}\text { Kurang Tu } \\
\text { Cukup Tu } \\
\text { Tuntas Ba } \\
\text { Sangat Tu }\end{array}$ & & & & & & \\
\hline
\end{tabular}

Perkembangan siswa bisa dilihat kaitannya terhadap hasil belajar dari hasil posttest yang dilakukan pada akhir pembelajaran. Menurut Novita (2013), " Hasil belajar adalah kemampuan yang diperoleh seseorang setelah mendapatkan kegiatan belajar mengajar. Hasil belajar itu merupakan behavior (tingkah laku) dan performance (penampilan) yang menunjukkan sesuatu yang dapat diamati oleh orang lain". Pada model pelatihan berbasis metode praktikum meliputi lima tahap yaitu: Tahap menentukan tujuan pembelajaran, menjelaskan teori, mendemonstrasikan, mempraktekkan dan mentransfer pelatihan. Melalui kelima tahapan tersebut guru menyampaikan informasi tentang materi pokok besaran dan satuan dengan ceramah, kemudian memberikan penguatan materi dengan cara bertanya kepada siswa secara acak untuk mengetahui apakah siswa mampu memahami materi yang disampaikan oleh guru.

Kemudian guru mendemonstrasikan cara - cara penggunaan alat dan langkah kerja praktikum kepada siswa dan jemudian menyuruh perwakilan salah satu siswa untuk mengulang kembali demonstrasi yang diperagakan guru. Dengan adanya pengulangan pengulangan tersebut maka siswa akan semakin ingat tentang materi yang dipelajari. Pada tahap mempraktek, guru menyuruh siswa untuk mempraktekkan hal - hal yang harus dilakukan ketika praktikum berlangsung sesuai petunjuk yang terdapat dalam LKS yang telah dibagikan guru dimana pada tahap ini siswa mempraktekkan secara langsung bagaimana cara menggunakan alat- alat pengukuran massa, panjang dan waktu dan membaca hasil pengukuran dari alat - alat tersebut. Perkembangan siswa dalam menggunakan alat - alat praktikum sangat baik. Awalnya siswa tidak mengenal alat - alat ukur tersebut dan manfaatnya, namun setelah diberikan pelatihan siswa menjadi tahu dan mengerti cara - cara penggunaan alat dan membaca hasil pengukuran. Siswa menjadi lebih aktif bertanya dan bekerja ketika praktikum berlangsung. Menurut Al - Farisi dalam Gunawan (2013), " Metode praktikum adalah metode yang bertitik tolak dari suatu masalah yang hendak dipecahkan dan dalam prodesur kerjanya berpegang pada prinsip metode ilmiah". Dengan demikian siswa dituntut untuk mengalami sendiri, mencari kebenaran, atau mencoba mencari suatu hukum atau dalil, dan menarik kesimpulan atau proses yang dialaminya itu. Pada saat pembelajaran berlangsung keterlibatan siswa cukup baik meski masih ada beberapa siswa yang melakukan aktivitas - aktivitas yang tidak relevan dengan pembelajaran seperti permisi keluar kelas. Aktivitas bertanya dan kerja paling sering muncul pada fase pembelajaran praktik dibandingkan pada fase - fase lain.

Namun demikian penggunaan model pelatihan berbasis metode praktikum ini memiliki beberapa kendala dalam proses pembelajaran diantaranya adalah keterbatasan alat - 
alat yang dibutuhkan untuk kegiatan praktikum, pengelolaan kelas oleh guru masih belum kondusif, keterbatasan waktu yang dibutuhkan saat praktikum berlangsung dan guru kadang kewalahan dalam melaksanakan pembimbingan terhadap kelompok secara bergiliran. Kendala ini diatasi guru dengan memberikan sanksi kepada kelompok siswa yang ribut dengan cara mengurangi nilai dari hasil kerja yang diperoleh kelompok siswa tersebut, guru berusaha semaksimal mungkin memanfaatkan waktu sesuai dengan RPP walaupun pada kenyataannya tidak bisa seefektif seperti yang telah direncanakan, guru mengatur di dalam pengelompokkan siswa secara heterogen, yaitu di dalam tiap - tiap kelompok terdiri dari siswa pintar maupun yang kurang pintar sehingga diantara mereka bisa saling bertransfer pengetahuan dan mempermudah tugas guru memberikan pembimbingan.

Pada kelas kontrol diberi perlakuan dengan menerapkan pembelajaran konvensional. Adapun metode yang digunakan berupa metode ceramah, diskusi dan tanya jawab. Pada saat kegiatan pembelajaran berlangsung siswa terlihat banyak yang jenuh terhadap materi pelajaran yang disampaikan oleh guru. Hal ini dikarenakan metode - metode belajar yang disampaikan guru kurang menarik minat siswa. Terkadang terlihat siswa yang mengantuk, mengusili temannya yang lain dan tidak konsentrasi penuh terhadap materi yang disampaikan guru. Hal ini berdampak pada daya tangkap siswa terhadap materi menjadi kurang baik, sehingga dapat dilihat dari hasil posttest siswa diperoleh rata - rata 69,1 dengan nilai tertinggi 90 dan nilai terendah 50 .

Pengujian hipotesis dilakukan dengan menggunakan uji kesamaan rata - rata dua pihak untuk mengetahui adanya perbedaan antara hasil belajar siswa pada kelas yang diajarkan dengan menggunakan model pelatihan berbasis metode praktikum dan kelas yang diajarkan dengan menggunakan pembelajaran konvensional pada materi pokok besaran dan satuan. Pada posttest diperoleh $t_{\text {hitung }}=5,08$ sedangkan $t_{\text {tabel }}=1,99$. Karena $t_{\text {hitung }}>t_{\text {tabel }}$, maka $t_{\text {hitung }}$ menunjukkan angka signifikan yang berarti. Berdasarkan hasil ini dapat dilihat bahwa ada perbedaan hasil belajar siswa (posttest) yang diajar dengan menggunakan model pelatihan berbasis metode praktikum dan pembelajaran konvensional pada kedua kelompok siswa. Hal ini menunjukkan bahwa penguasaan siswa terhadap materi besaran dan satuan lebih baik apabila menggunakan model pelatihan berbasis metode praktikum daripada pembelajaran konvensional.

\section{PENUTUP}

Berdasarkan hasil penelitian yang diperoleh dari hasil analisa data dan pengujian hipotesis maka dapat disimpulkan bahwa ada perbedaan yang signifikan terhadap hasil belajar siswa dengan menggunakan model pelatihan berbasis metode praktikum dan pembelajaran konvensional pada siswa SMAN 1 Meulaboh T.P 2016 / 2017 pada materi pokok besaran dan satuan antara kelas eksperimen dan kelas kontrol dengan hasil pengujian $t_{\text {hitung }}>t_{\text {tabel }}(5,08>$ 1,99) pada taraf signifikan $\alpha=0,05$.

\section{UCAPAN TERIMAKASIH}

Ucapan terimakasih peneliti ucapkan kepada pihak unuversitas teuku umar yang telah mendukung proses administrasi peneliti selama proses penelitian. Kepada pihak sekolah SMAN 1 Meulaboh yang telah memberikan izin kepada peneliti untuk melakukan penelitian di sekolah tersebut. Kepada seluruh siswa kelas X SMAN 1 Meulaboh yang telah bersedia menjadi objek penelitian serta berbagai pihak yang tidak mungkin peneliti tuliskan satu persatuan.

\section{DAFTAR PUSTAKA}

Gunawan, E. 2013. Macam - Macam Metode Pembelajaran 
.http://nilaieka.blogspot.com/2013/04/macam-macam-metode-pembelajaran.html.

Halimah, S. 2012. Strategi Pembelajaran. Penerbit Cita Pustaka Meida Perintis. Jakarta.

Kurnianto, P. 2010. Pengembanagan Kemampuan Mengumpulkan dan Mengkomunikasikan Konsep Fisika Melalui Kegiatan Praktikum Fisika Sederhana, Jurnal Pendidikan Fisika Indonesia 3(6). Hal. 57.

Novita, A. 2013. Pengaruh Pemakaian Metode Praktikum Terhadap Hasil Belajar Siswa Pada Pokok Bahasan Laju Reaksi, Jurnal Matematika dan Sains. 3(1). Hal.30.

Sumintono, B. 2010. Pengajaran Sains Dengan Praktikum Laboratorium: Perspektif Dari Guru - Guru Sains Di SMPN Di Kota Cimahi, Jurnal Pengajaran MIPA. 2(15). Hal. 121.

Wibowo, W. 2009. Perbedaan Hasil Belajar Siswa Kelas VIII Semester I Pada Pokok Bahasan Cahaya Dengan Model Pelatihan Berbasis Kegiatan Praktikum Dan Pengajaran Konvensional Di SMP Negeri 38 Medan T. P. 2009/2010. Skripsi. FMIPA UNIMED. Medan. 